\title{
Bureaucracy Reform in Magelang City: Present Portraits and Future Design
}

\author{
Samodra Wibawa ${ }^{1}$, Eny Boedi Orbawati ${ }^{2}$, Arnanda Yusliwidaka ${ }^{3}$, Koentjoro $^{4}$, Fadlurrahman $^{5}$ \\ \{Samodra03@yahoo.com ${ }^{1}$, enyorbawaty@yahoo.co.id ${ }^{2}$, papierarnanda@gmail.com ${ }^{3}$, \\ koentjoro@gmail.com ${ }^{4}$, fadlurrahman@untidar.ac.id $\left.{ }^{5}\right\}$ \\ Gadjah Mada University ${ }^{1}$, Tidar University ${ }^{2}$, Tidar University ${ }^{3}$, Tidar University ${ }^{4}$, Tidar University ${ }^{5}$
}

\begin{abstract}
This research describes the traces of the bureaucracy reform process in Magelang City through the identification of eight bureaucracy reform changes together with monitoring, evaluation and reporting that has occurred since 2012 and designed alternatives Bureaucracy reform model for the future. The Method used is a qualitative method with several data collection techniques including questionnaires, Focused Group Discussion (FGD), in-depth interviews, and observations. The results are: (1) the reform journey of Magelang City, which started, from 2012 there are still many shortcomings, one of the leadership commitment still not focused on reform bureaucracy. The proof of Concertina is that when the city of Magelang gets a fair With No Exceptions (WTP), but the terms to bear the opinion of WTP not noticed; (2) the model designed conceptualized from the various shortcomings of the reform experienced by Magelang City.
\end{abstract}

Keywords: Bureaucracy Reform; Administration Reform; Transformation Area, Bureaucracy, Magelang City.

\section{Introduction}

Since the beginning of the third millennium, the Government of Indonesia Republic of is relatively committed to conducting State administration in general and government bureaucracy in particular. In addition to the spirit of reform in 1998 is also because of the urges, guidance, and mentoring of foreign institutions or the world. The local government is not left out of this process, either because of its own will and because the central instruction also reformations itself.

Bureaucratic reforms delivered to all government devices, both at the central and regional levels. The universal principle is the good governance and clean Government in providing excellent service to the community as the recipient of the service itself. Citing Russian experience in the context of the law, Service innovations are the essence of reform and management in this country [1]. Therefore, the existence of bureaucracy functioning is as a mechanism of service system continuity in management and governance of public problems [2]. Especially the street-level bureaucracy was because they interact directly with the community in providing public services [3]. In this regard, it is very important to build a state apparatus 
through bureaucracy reform in order to materialize the public service that is responsive, transparent, effective and efficient.

Slowly but surely, the bureaucracy reform in Indonesia has been running since 2004 called Wave I bureaucracy reform with the tempo of the next five years. Then forwarded back through the road map of the bureaucracy reform Wave II from the years 2010 - 2014, even today, there has been a grand design bureaucracy reform 2010-2025 as a reference to every central and regional institution to reform itself. On that basis, it seen that there is a great desire from the government to change governance to be better than the highest level to the lowest by creating new breakthroughs gradually, realistically, Concrete, and earnest. In order to realize what desiring, then it is necessary to do a review or review of the bureaucracy reform process that has been running, and look the access of bureaucracy in reforming itself.

In this research, the study of bureaucracy reform conducted in Magelang City by reviewing the success, shortcomings and obstacles during the process of bureaucracy reform. Magelang City itself has organized bureaucracy reform in 2012 with the guidance of [4] about Grand Design bureaucracy reform during the period 2010-2025. However, during the process that has been running the score produced by Magelang City is still relatively low, with a score of 65 . This studied more in relation to the bureaucracy reform process in Magelang City. Therefore, this research will also identify eight areas of change in the micro level that exist in the Grand Design bureaucracy reform during the period 2010 - 2025. It is including: Change management, structuring legislation, structuring and Strengthening organizations, organizing governance, structuring human resource management systems, strengthening supervision, strengthening performance accountability, improving the quality of public services, and together with monitoring, evaluation and reporting.

The review of Magelang City bureaucracy reform will further benefit both the academic world and the Government of Magelang itself. Later this study also used as an example or a picture of the improvement of bureaucracy reformation in other regions in Indonesia.

\subsection{Literature Review}

\section{Bureaucracy Reform}

Bureaucratic image as a public sector has declined in the eyes of society. Based on several research results, the public sector stated to be inefficient and ineffective compared to the private sector and it had become a common belief among the community [5]. Comparison between the public and private sectors in academic studies has done for example on the level of decisionmaking, performance of members, innovations, management skills, objectives, and marketing and technology that addressed the Far behind the private sector [6]-[13]. Therefore, the bureaucracy must reform itself in order to create a service equivalent to the private sector.

[14] mentioned that the first step to improving the development and progress of a country is to reform its institutional institutions. Reform is a movement to alter the shape and behavior of a setting, because the order is no longer suitable applied or used. The reason could be based on because the order was not in accordance with the needs of the era or there was a gap that can be manipulated so that it is inefficient, not clean, and not democratic and others [15].

[16] suggested that bureaucratic reform refers to an attempt to moderate the state apparatus that was previously traditional, becoming more professional. If so, bureaucracy reform is an extension of the process of administrative reform. When administrative reform talks about changes by making changes to the aspects of structures and functions, the behavior patterns of members in an organization/bureaucracy to achieve administrative effectiveness [17], then the bureaucracy reform more The whole aspect of bureaucracy to create effective service. Later [18] 
concluded that in general bureaucracy reform was a change that includes proactive transformation and reactive bureaucracy adaptation (including its objectives, institutions, structures, norms, attitudes and group targets).

Assessing the internal quality of a bureaucracy, the assessment of a good bureaucracy generally shows some indications of the following behavior. To process the work stably and vigorous, treating the individual fairly and balanced, Hiring and maintaining officers based on the level of professionalism and orientation to program successful, promoting staff based on merit system and proven work, and performing the maintenance of achievements Accomplished by [15], [19], [20]. In the context of public administration, bureaucracy behavior and reform principles always related to the public interest associated with the output (goods and services) provided. It is also that will be the judgment of the bureaucratic quality externally (from society/public). Bureaucracy should have a responsive nature to the public interest in order to reform itself. In representative bureaucracy theory, responsiveness created when the composition of a bureaucratic demographic represents the demographic of the community served or client communities [21]. The representation can be seen from the values, beliefs, races, ethnic and gender in the bureaucracy [22].

Bureaucracy Reform in the grand design of Indonesian bureaucracy reform in 2010-2025, which is a major change in the paradigm and governance of Indonesia. In line with this, in regulation of [4] about Grand Design bureaucracy reform 2010-2025, it is said that the bureaucracy reform needs to be done in all ministries/institutions/local governments with To accelerate the achievement of good governance. The term governance is the Government's capacity to effectively formulate and implement policies (Kaufmann, et. al., 2009). Good governance has a wide range of dimensions that are indicators of its assessment size: quality of regulation, rule of law, political stability, government effectiveness, accountability and control of corruption, openness, participation, coherence, Quality of service, productivity, responsiveness, and responsibility [23]-[25]. Thus, [26] said that good governance meant good administration because it characterized by not only the participation of community at the local level, but also characterized by the rules of law, responsiveness and efficiency.

\section{Bureaucracy Reform Policy in Indonesia}

The reform Era that began in 1998 seemed to change governance in almost all areas. Since then, many important changes have been made in the body of government, which aims to provide excellent service to the community. In 2004, bureaucratic reform began implemented massive, known as the Wave reform I with the main program of building quality State apparatus through the application of bureaucracy reform. However, the Wave I only managed to reform the field of politics, economics and law, while the bureaucracy itself had a lag (quoted from the Grand Design bureaucracy reform 2010-2025).

The commitment to successful bureaucracy reform then demonstrated by all ministries and institutions. So that specifically the government issued a [4] on Grand Design bureaucracy reform as a direction of the implementation of bureaucracy reform for the period $2010-2025$. The policy followed up with The Regulation of Ministry of Administrative and Bureaucratic Reform No. 20 in 2010 about Bureaucracy Reform during the period 2010-2014 Road map, which became the reference in the preparation of the Road Map of the Ministry and institutions. It is known as Wave II bureaucracy reform (quoted from Ministry of Administrative and Bureaucratic Reform, 2014, Indonesian Bureaucracy Reform Achievement and Forward Policy Direction). For the issuance of the Presidential decree, the local government also expected to welcome the long-planned change in accordance with two government regulations namely. Ministry of Administrative and Bureaucratic Reform No. 30 in 2012 about the guidelines, 
proposals, determination and Development of bureaucracy reform on local government and Ministry of Administrative and Bureaucratic Reform No. 37 in 2013 about guidelines for drafting Road Map of bureaucracy reform of local government.

\section{Grand Design, Road Map, and Indonesian Bureaucracy Reform Direction}

Based on the structure of the grand design bureaucracy reform 2010-2025, grand design is a master design that contains the policy direction of national bureaucracy reform for the period of 2010-2025. Grand design of its own bureaucracy reform that stipulated by Presidential Decree. The scope of the grand design bureaucracy reform focused on government bureaucracy reform with the aim of giving the policy direction of national bureaucracy reform during the period 2010-2025 and as a guideline in of bureaucracy reform road map every five years. Then, in the grand design bureaucracy reform, there are nine areas of change (programs) that are on the micro level, namely: change management, the arrangement of legislation, structuring and strengthening the Organization, organizing governance, Setting up of Human Resource management systems, strengthening supervision, strengthening performance accountability, improving the quality of public services, as well as monitoring, evaluation and reporting.

The principles of bureaucracy reform in the context of the development of the State administration system include democracy and empowerment, service, transparency, participation, partnership, decentralization, and the consistency of policy and legal certainty. Various principles of bureaucracy reform when able applied; it will achieve the expected objectives as stated in the Grand Design bureaucracy reform 2010-2025, including as follows:

- $\quad$ Reducing and eliminating any misuse of public authority by officials in the relevant agencies.

- $\quad$ Making the country that has the most-improved bureaucracy.

- Improving the quality of service to the community

- Improving the quality of formulation and implementation of the program/institution

- Improving efficiency (cost and time) is in the implementation of all facets of organizational tasks.

- Making Indonesian bureaucracy is such as anticipatory, proactive, and effective in dealing with globalization and the dynamics of strategic environmental change.

Furthermore, the means of road map bureaucracy reform is the form of operationalization grand design bureaucracy reform which is compiled and conducted every 5 (five) year and is a detailed plan of the bureaucracy reform from one stage to the stage For the next 5 (five) years with clear per-year objectives. Road map of bureaucracy reforms on its own set by Ministry of Administrative and Bureaucratic Reform. The purpose of the preparation of bureaucratic reform road map is to provide the direction of bureaucracy reform in the ministries, institutions and local governments in order to run effectively, efficiently, measurable, consistently integrated instatement and Sustainable. The following images of the grand design bureaucracy reform 2010-2025 with the road map bureaucracy reform. 


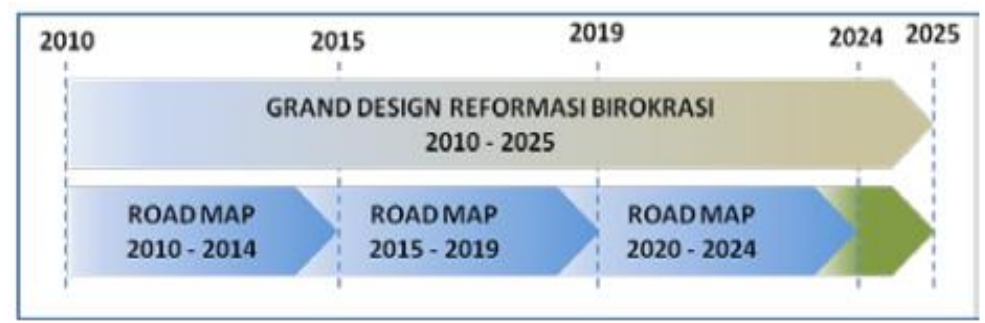

Source: Grand Design Bureaucracy Reform 2010-2025

Fig 1. Relation to the Grand Design of Bureaucracy Reform 2010-2025 together with Bureaucratic Reform Road Map 2010-2014, 2015-2019, and 2020-2024

With the vision of "realization of world class governance", the direction of bureaucracy reform policy established under [27] about RPJPN 2005-2025. The development of State Apparatus conducted through bureaucracy reform to improve the professionalism of state apparatus and to realize good governance, both in the center and in the region in order to support the success of development in other areas and Presidential Decree No. 5 in 2010 about RPJMN 2010-2014. Development policies in the field of law and apparatus directed at the improvement of good governance through the implementation of bureaucracy reform.

\section{Methodology}

Method used is a qualitative method with several data collection techniques including questionnaires, Focused Group Discussion (FGD), in-depth interviews, and observations. The data analysis technique follows the interactive models from [28] in [29] with data reduction phases, data presentation, and conclusion withdrawal (data verification).

\section{Finding and Discussion}

\section{Bureaucracy Reform in Magelang City}

The bureaucracy reform in Magelang City backed by the demands and needs of a qualified apparatus in the local government of Magelang City. The successful indicator of the bureaucracy reform in Magelang City is not because of the simplified procedures or the reports that have been presented alone, but the indicator is very well-rounded if the society is getting Service can feel a better change with the criteria of fast, easy, cheap, and transparent.

The basis of bureaucracy reform in Magelang City refers to [4] about Grand Design bureaucracy reform during the period $2010-2025$ which is to be implemented and put down Road Map bureaucracy reform every 5 (five ) years in government agencies. Road Map of bureaucracy Reform was during the period 2015 - 2019 stipulated by Ministry of Administrative 
and Bureaucratic Reform No. 11 in 2015. This basic is formed and implemented bureaucracy reform in Magelang City, especially for the local government of Magelang City.

The implementation of bureaucracy reform in Magelang City is implemented to realize the high-performance, clean and accountable local government bureaucracy of Magelang City, and able to use the resources owned efficiently for the benefit of Public so that the community can feel better service changes. The change of service in question executed by various steps as follows:

\section{a. Organization Mapping}

The arrangement of Local Government Organization (OPD) of Magelang City held under Government Regulation No. 41 in 2007 and Regional Regulation of Magelang City Number 20, 21, 22, and 23 in 2007. The arrangement of the government organization of Magelang City, among others, originally had the number of Regional Device Work Units known as (SKPD) amounted to 46 SKPD and the structural position of Echelon $\mathrm{V}$ up to Echelon IIa amounted to 590 positions. It is efficient to 29 SKPD, the term SKPD, transformed into a Regional Device Organization (OPD) and 549 of Echelon IVb structural positions with IIa. This efficiency affected by the reduction in structural positions of 43 structural positions. The arrangement of the organization has been adjusted to the Government Regulation No. 18 in 2016 and Magelang City Regulation No. 3 in 2016.

\section{b. High Leadership Department}

On the agenda of Bureaucrat ion reform in the filling section of the High Leadership Department (JPT) in the local government area of Magelang City, the local government of Magelang City is using open selection and no longer uses The Mechanism of Position Consideration Agency and the Generation known as (BAPERJAKAT). It implemented so that the right man in the right place principle can happen.

c. To Implement Motivation, Discipline, Work Ethic known as (MDE), reward, and punishment consistently

The implementation of MDE, reward, and punishment by local government of Magelang City include as follows:

- Award from the mayor to the employees who are present at the earliest times, appreciate the quality of human resources but still do not forget the seniority.

- Using a discipline variable as one of the important considerations in the development of an employee career, (not just a variable work target employer/employee performance) because the sanctions set in Government Regulation No. 53 in 2010 considered too light.

- Leader of bureaucracy in the local government of Magelang City is invited and always reminded to be role model, and professional in working (there is no conflict of interest).

Bureaucratic reform is a strategic step to build state apparatus to be more empowered in carrying out governmental tasks and national development. In the city of Magelang, the implementation of bureaucracy reform has begun since 2012 expected to have a significant impact on performance enhancement as well as public service reform. The preparation of master plan of reformation bureaucracy of the city of Magelang City could emphasized on the preparation of the Bureaucratic Reform Road Map abbreviated as (RMRB). 
RMRB is a form of the operationalization of the Grand Design Bureaucracy Reform (GDRB), which compiled and conducted every 5 years, which contains of detailed plan. Implementation is starting from step one to next stage for 5 years with a clear goal of the year. Goals in the following years also refer to the target in the previous year. Bureaucratic reform has the objectives and objectives described in the following table.

Table 1. Objectives and Targets of Bureaucracy Reform

Goals
To create a clean, intelligent, high-
working and professional apparatus
that is able to provide service to the
community optimally

Creating a government that is able to ruin with the rules of law and legislation, so the government can run well

\section{Targets}

- To realize administrative management that is good and orderly from framework of organizing professional governance to the excellent public service.

- To realize condition is such as a clean government, responsive, accountable and accountable government.

- Realization of public service that is fast, transparent and fair.

- The treatment of apparatus that is reflects the values of good governance.

- Realization of the quality of the document planning of the construction of participatory documents that is in the framework of public service quality.

- The creation of a reciprocal relationship is between the Government, Regional Representatives, the business world, democracy-based society and information transparency.

- Realization aims to increase law enforcement and fair legal capacity for all.

- Realization aims for local government adherence to statutory regulations.

Most of each region has been or is still in the process of implementing bureaucracy reform, and this is a must-do order. However, in the implementation and quality vary, and it determines the value achieved by each region. The value of Magelang City itself is still 65. There are eight areas emphasized on the bureaucracy reform, namely change management, legislation, structuring and strengthening of the Organization, governance arrangement, structuring Management of Human Resources apparatus, strengthening supervision, strengthening Work accountability, improvement of public service quality and, monitoring evaluation as well as reporting.

\section{Changing Management}

Changing management relates to the culture of positive work conducive to the creation of clean, accountable, effective and efficient bureaucracy and able to provide quality service. The effectiveness of change management can generate great productivity, high quality of life and increase readiness for future changes [30]. [31] said that a good relationship between the member and the organization's leadership will make it easier to implement changes in an organization.

The aspects related to change management are the commitment of government leaders to reform; Employees' commitment to reform; Changing mindset and working culture; and changing system and work culture. The target that achieved from the management of this change is the increasing commitment of leadership and government employees of Magelang City and Regional Device Organization $(O P D)$ in conducting bureaucracy reform. The changing mindset 
and the working culture of all employees is even better; Lowering the risk of failure caused by the possibility of resistance to change; and formed of Regional Action Planned known as (RAD) related to bureaucracy reform.

Based on the results in the field, the target in the change management area mentioned above has not reached the maximum. There is still an in connection between the executor and Agency for Regional Development abbreviated as BAPPEDA. It has not yet been Regional Action Planned known as $(R A D)$ formed, and only a few units have opened themselves to do bureaucracy reform. Obstacles are certainly affecting the bureaucratic reform process. Consequently, if seen based on numbers, hence the value of bureaucracy reform in the change management Area still multiplied by 0.87 . It should be when three categorized into the letter A

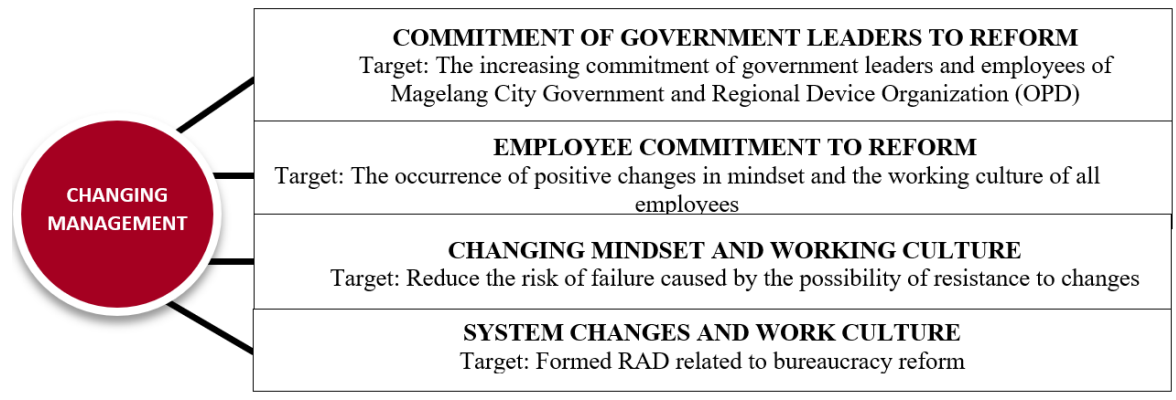

Fig 2. Reformation Diagram of the Change Management of Area Bureaucracy

\section{Constitutional Laws}

The number of legislation that overlaps, harmonized, can be interested differently or deliberately made unclear to open up the possibility of deviations. The apparatus often utilizes such conditions for personal interests that harm the country. It is necessary to change/strengthen the regulatory system that is more effective and touching the needs of the community. Aspects of the arrangement of legislation in Magelang City are as follows:

a. Identification of the analysis of the unharmonious legislation has implemented with evidence of circular letter of the district secretary.

b. It has been conducted a review of the laws and regulations that are not harmonious.

c. The control system in the preparation of the manuscript is already present, proven by the presence of academic texts and coordination meetings.

d. The analysis of the laws and regulations are not harmonious, the analysis has proven by circular letter of the District Secretary of Magelang City.

e. Review of the laws and regulations that are not harmonious, done by the Government of Magelang City.

f. Control system in the preparation of the manuscript, this control system proven by the presence of academic texts and various coordination meetings. 
The goal achieved from the arrangement of this legislation is the declining overlap and the Unharmonious of legislation issued by the local government of Magelang City and Regional Device Organization (OPD).

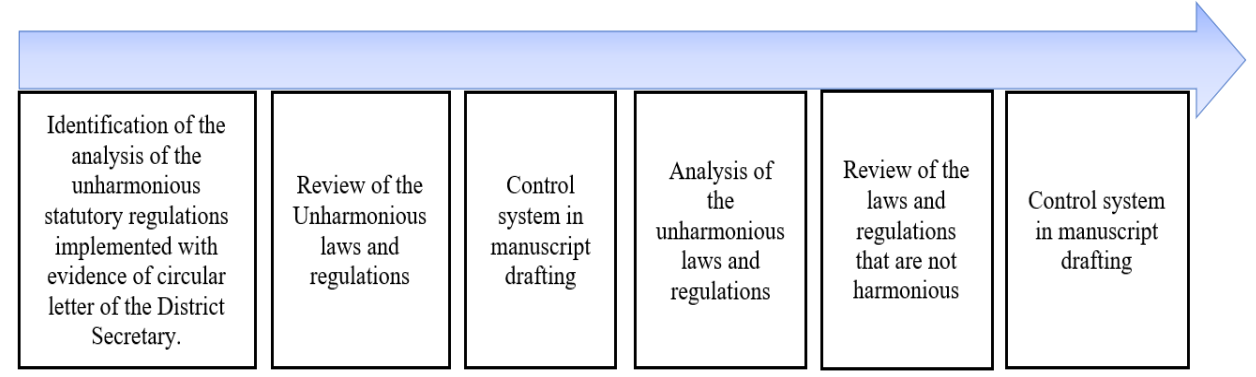

Fig 3. Flow Diagram Harmonization of Statutory Regulations

\section{Organization Setup and strengthening}

Aspects of organizational structuring and strengthening include the harmony of principal tasks and functions of the Regional Device Organization or OPD; OPD capacity adjustment, number and size of Regional Device Organization or OPD (right sizing). The Target achieved in organizing and strengthening of the organization is decreasing the overlap of principal tasks and functions of the Government City and the organization of local devices in the area of Magelang City. The next Target is to increase the capacity of local government of Magelang City nd OPD in carrying out basic tasks and functions.

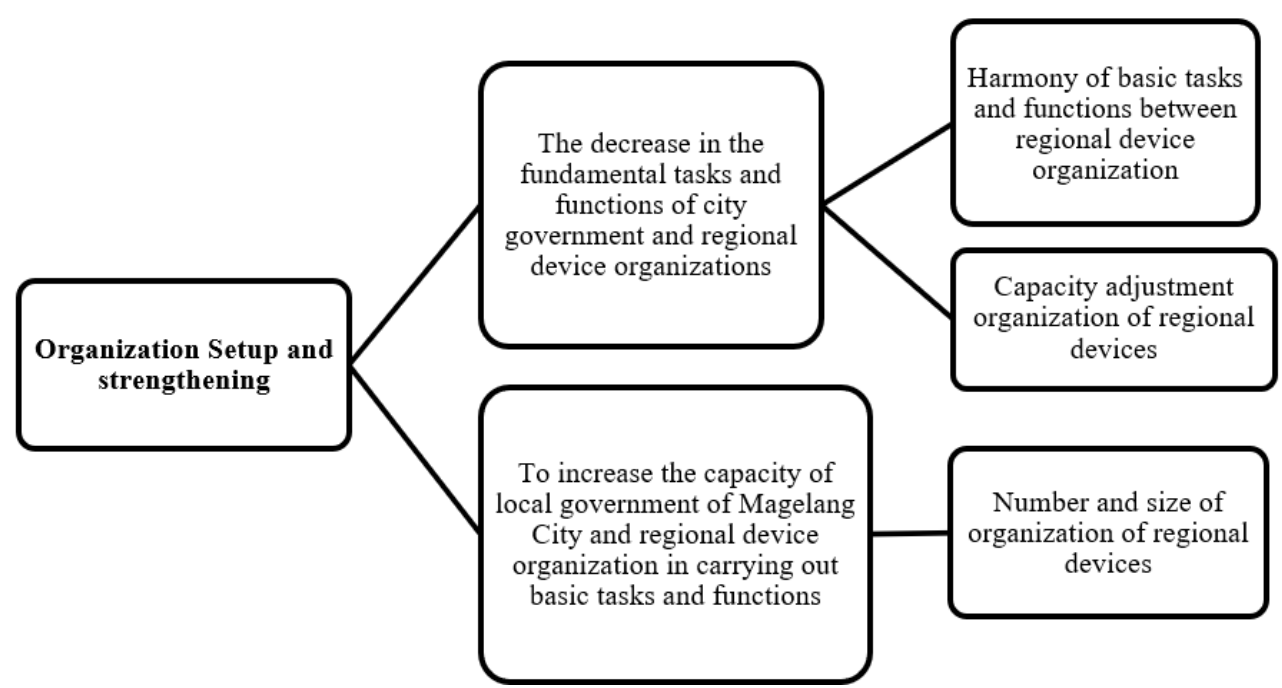

Fig 3. Diagram of Bureaucracy Reform Area Setup and Strengthening Organization 


\section{Execution}

Governance execution aims to encourage the efficiency of governance and service, as well as to change mental apparatus. Aspects that become the focal point of governance include the use of information technology, the effectiveness of government management processes, the efficiency of the governance process; and Regional Device Organization $(O P D)$ performance. The Target is to achieve the increasing use of information technology in the process of organizing government management in government related to government agencies, increasing the efficiency and effectiveness of government management processes, and Performance in Magelang City government and other government agencies.

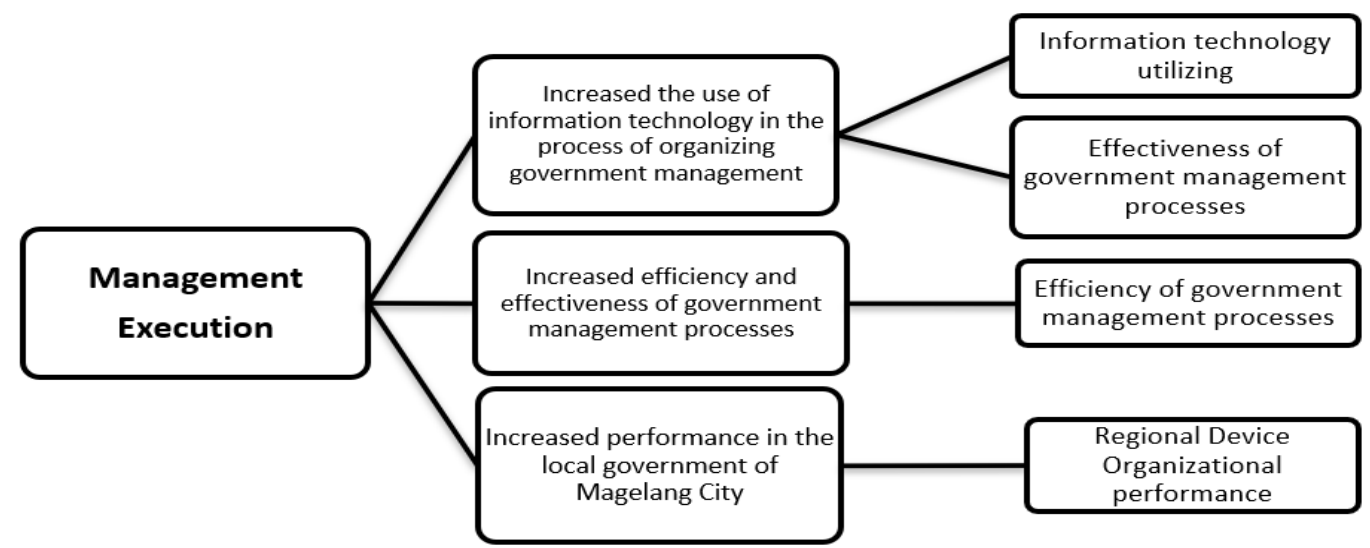

Fig 4. Target Diagram Of Bureaucracy Reform Area of Management

\section{Setting up Human Resource Management System of Apparatus}

The arrangement of human resources management system aimed at producing human resources professional apparatus. Aspects that become measurements in this case are: human resource management according to the rules, transparency of human resource management, accountability of human resource management, human resources discipline, human resources professionalism, human resource management effectiveness, recruitment and promotion of apparatus according to competency, Recruitment and promotion of apparatus transparently, and the welfare of employees.

Target achieved is as follows first, increased obedience to the management of human resource apparatus in Magelang City government and related agencies. Second, to increase transparency is both of accountability management and of human resources apparatus. Third, increase Human Resource discipline of apparatus in all lines of Magelang City government. Fourth, increased Human Resource management effectiveness is going well. Fifth, increasing professionalism of human resources apparatus are around in Magelang City government and related agencies 


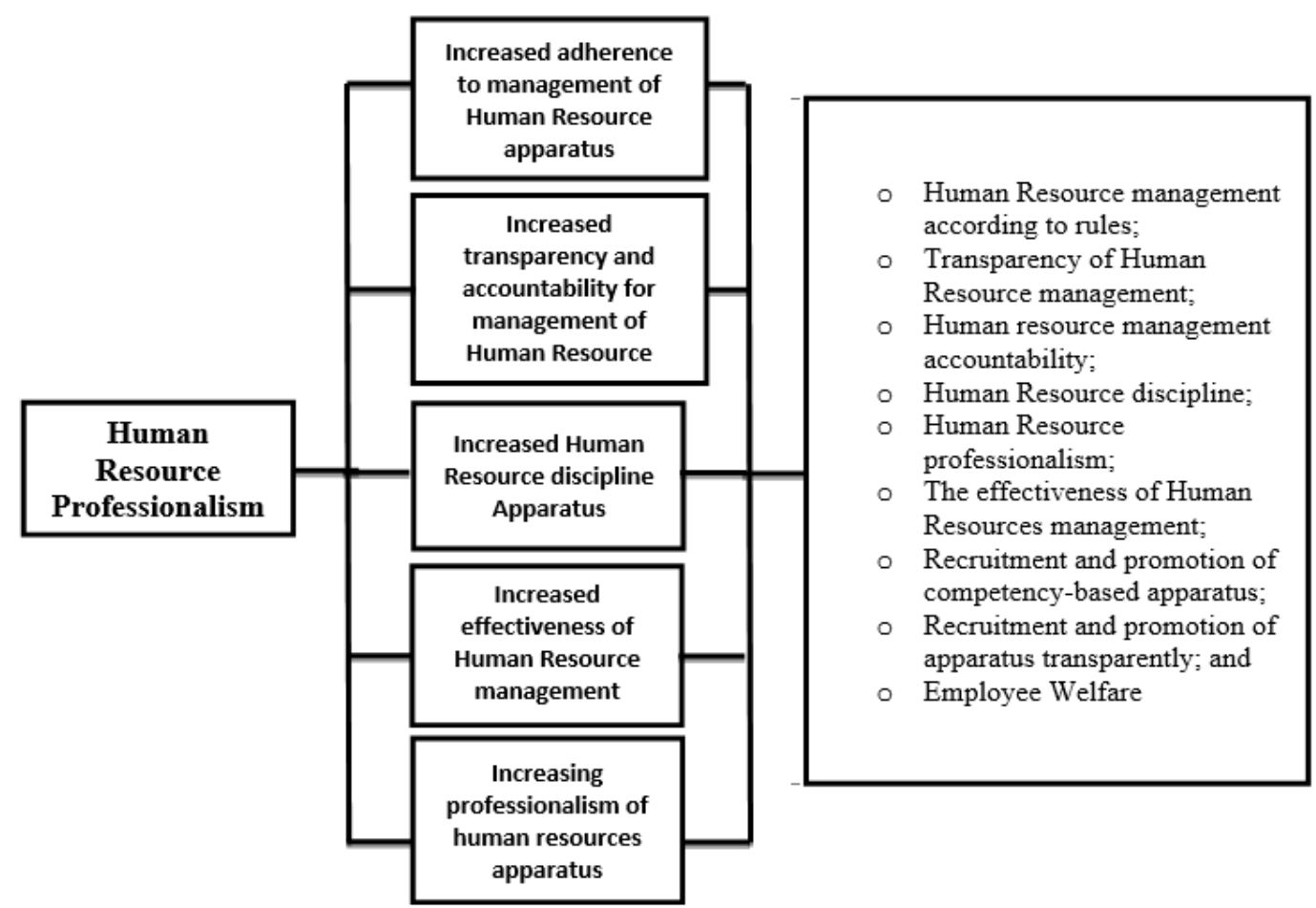

Fig 5. Diagram of the Bureaucracy Reform Area Setup of Human Resource Management System Apparatus

\section{Strengthening Supervision}

Strengthening and supervision aims to improve the implementation of the clean bureaucracy of deviant practices that are contrary to the law. Aspects of this strengthening and monitoring include as follows: financial management According to the rules, effectiveness of financial management, the status of Financial Supervisory Agency known as CPC opinion namely Corruption-Free Territories or Bureaucratic Territory Clean and Serve known as $W B K / W B B M$ and Reasonable without Exception known as WTP, control gratification, whistleblowing system, and SPIP. The target is to be reached by Magelang City Government, among others: increased compliance and effectiveness in the management of state finances, increased status of CPC opinion on the management of the state's finances, declining levels of abuse of authority and deviations by apparatus, and obtain a WTP opinion. 


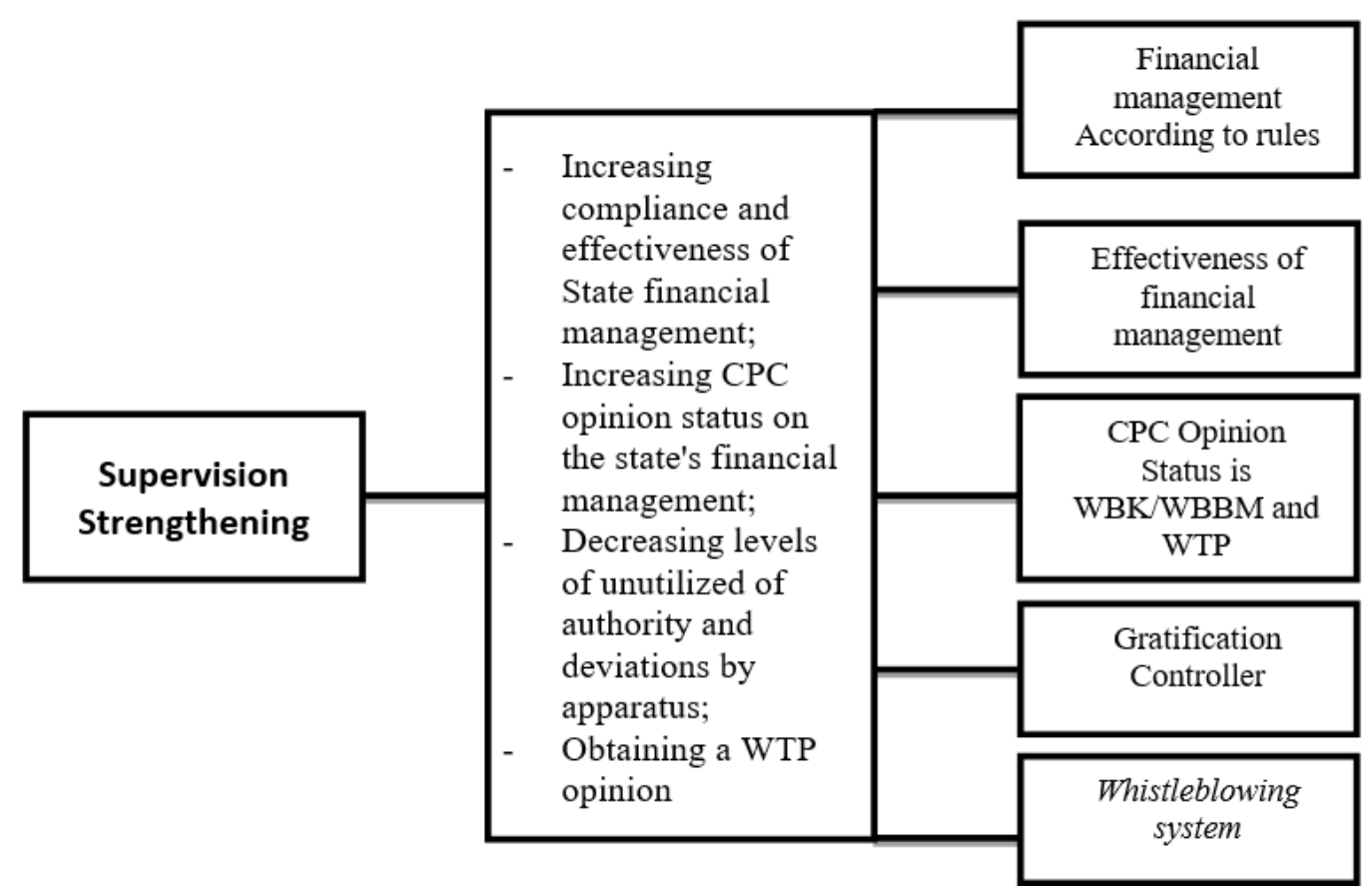

Fig 6. Diagram Reform Bureaucracy of Surveillance

\section{Strengthening Work Accountability}

The purpose of strengthening the accountability of work is a more performing bureaucracy and able to respond to its performance in accordance with the sources it uses. The change areas include as follows: Regional Device Organization $(O P D)$ working capacity, OPD performance, and OPD accountability. The target set by Magelang City Government is: to increase the quality of the implementation financial and performance systems and integrated, increasing the quality implementation of goods and services procurement system in a fair, transparent, and professional, increasing Implementation of performance management systems, and the increasing accountability of the apparatus itself. 


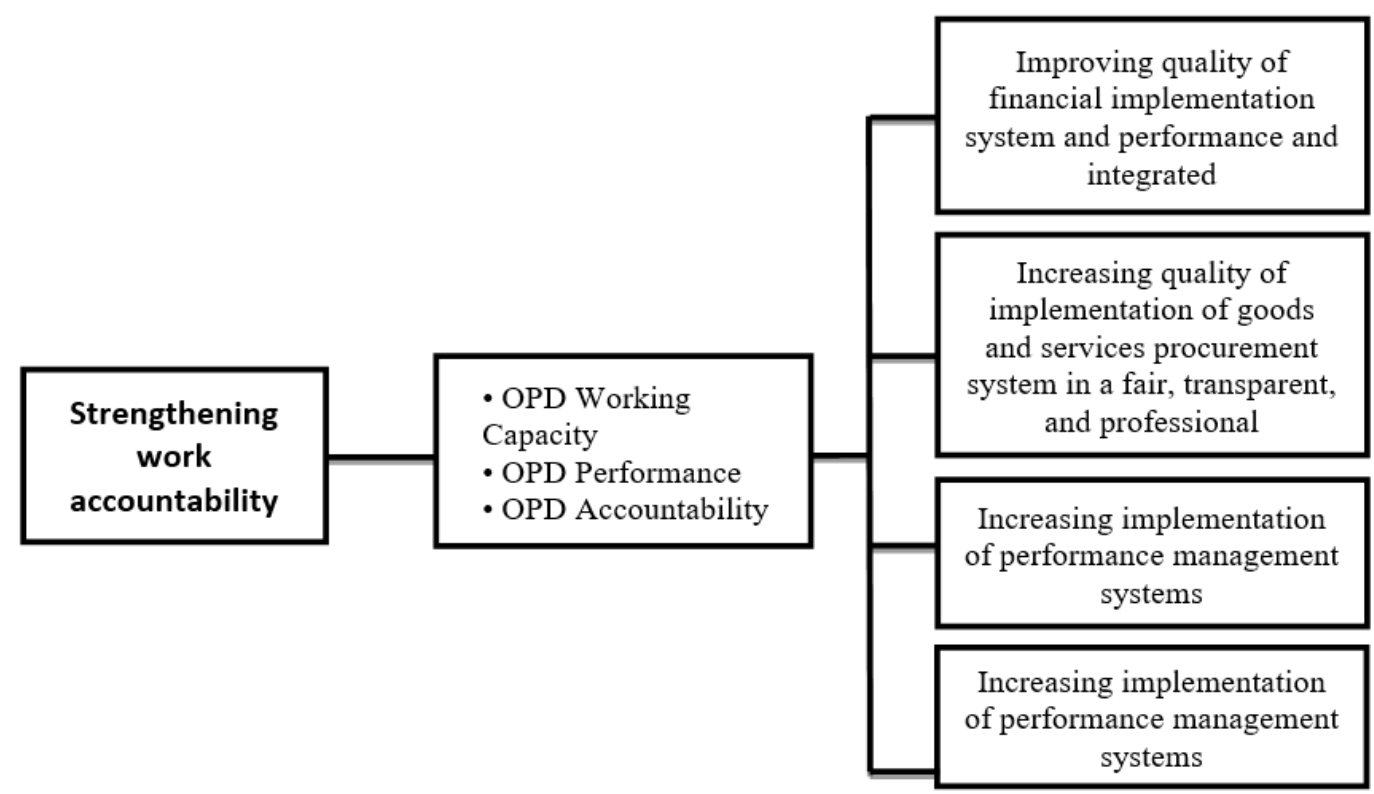

Fig 7. Bureaucratic Reform Diagram Of Surveillance

\section{Improvement of Public Service Quality}

Improving the quality of public services is as expected by the community and in accordance with excellent service. The focus of improving the quality of public services is as follows: service standards, media complaints, public satisfaction, and the utilization of information technology. Meanwhile, the target that is wanted to reach Magelang City Government in the matter of improving public service quality include increasing the quality of public services (faster, cheaper, safer, and easily accessible by the community). Increasing number of units Service that gained standardization of service, increased public satisfaction index of public services conducted by the Magelang City Government, and increased professionalism of apparatus. 


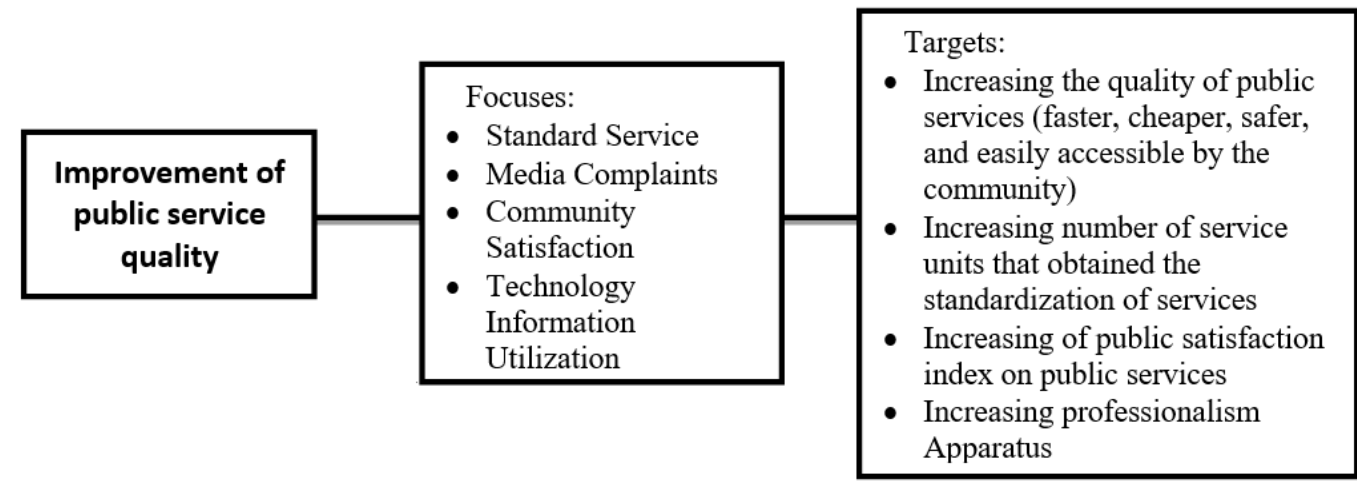

Fig 8. Diagram Reform Bureaucracy of Public Service

In addition to 8 areas of change planned and executed, Magelang City Government through the Inspectorate of Magelang City implementing programs monitoring, evaluation and reporting. This aims to make the implementation of bureaucratic reforms that carried out according to the provisions and targets stipulated in Magelang City Bureaucracy. The desired target is to provide early warning on the risk of failure of achieving the target set.

According to the target set by Magelang City Government to fix/reform itself so that its shortcomings corrected, in case of indispensable model alternatives (outlined in several strategic steps) that applied so that Bureaucracy City Reform was better. Here are alternative bureaucracy reform models that applied by Government City in all areas of the change.

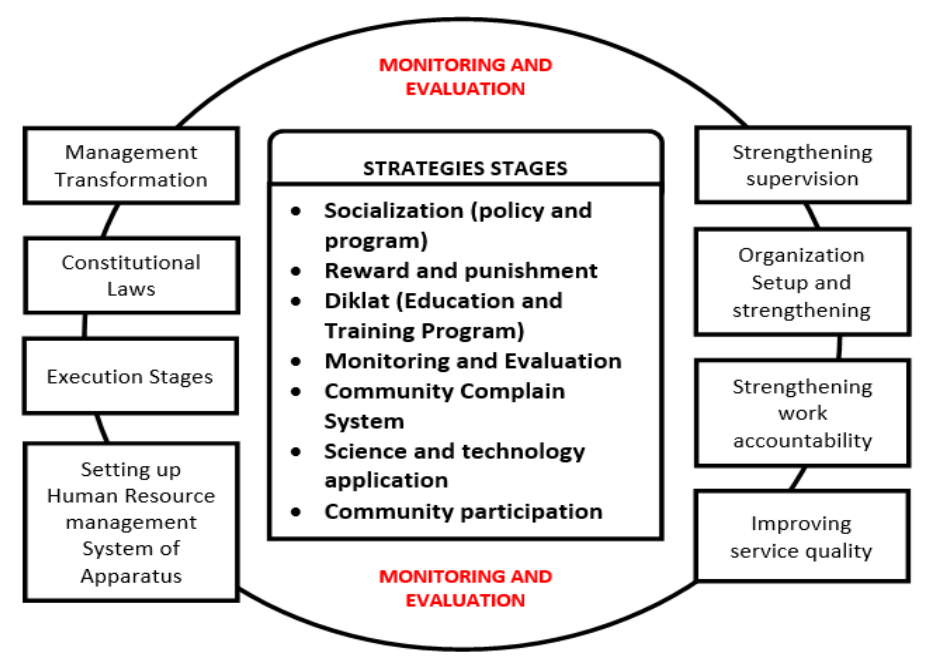

Fig 9. The Model of Alternative Bureaucracy Reform 


\section{Conclusion}

The implementation of bureaucracy reform in Magelang City is essentially running but there are still many shortcomings that must be formed in the future. Disadvantages Here are the commitments of the leadership for bureaucracy reform. One example is the government of Magelang has obtained a reasonable Predicate without Exception (WTP). Nevertheless, on the other side the condition that must be met to bear the WTP opinion is not noticed. However, Magelang City Government has a target for the implementation of bureaucracy reform in the future. In addressing the problems faced by the Magelang City Government, it is necessary that alternative models expected to be able to reform bureaucracy for the better and achieve the established targets. In order the implementation should also be Leadership and stakeholders in the government environment of Magelang City must have a strong commitment and realized to be an example of all employees in Magelang City Government. Start changing your mindset better to manage your governance without the sectorial ego that sometimes wants to carry out a personal mission for personal participation.

\section{References}

[1] S. Inkina, "Civil Service Reform in Transition: A Case Study of Russia," Rev. Eur. Russ. Aff., 2013, doi: 10.22215/rera.v8i1.222.

[2] M. Tanwir and S. Fennell, "Pakistani bureaucracy and political neutrality: A mutually exclusive phenomenon?," Pakistan Development Review. 2010.

[3] M. Lipsky, "Dilemmas of the Individual in Public Services," Street-Level Bur. Dilemmas Individ. Public Serv., 1980, doi: 10.1007/springerreference_76056.

[4] PERPRES No.81, Peraturan Presiden Nomor 81 Tahun 2010 tentang Grand Design Reformasi Birokrasi 2010-2025. 2010.

[5] "Towards Efficient Public Sector Asset Management," Financ. Theory Pract., 2009.

[6] P. C. Nutt, "Public-Private Differences and the Assessment of Alternatives for Decision Making," J. Public Adm. Res. Theory, 1999, doi: 10.1093/oxfordjournals.jpart.a024412.

[7] J. A. Andersen, "Public versus private managers: How public and private managers differ in leadership behavior," Public Adm. Rev., 2010, doi: 10.1111/j.1540-6210.2009.02117.x.

[8] S. Burgess, "The Role of Incentives in the Public Sector: Issues and Evidence," Oxford Rev. Econ. Policy, 2003, doi: 10.1093/oxrep/19.2.285.

[9] A. Weibel, K. Rost, and M. Osterloh, "Pay for performance in the public sector - Benefits and (Hidden) costs," J. Public Adm. Res. Theory, 2010, doi: 10.1093/jopart/mup009.

[10] H. C. Baarspul and C. P. M. Wilderom, "Do Employees Behave Differently In Public- Vs PrivateSector Organizations?: A state-of-the-art review," Public Manag. Rev., 2011, doi: 10.1080/14719037.2011.589614.

[11] P. D. Brewer and K. L. Brewer, "Knowledge Management, Human Resource Management, and Higher Education: A Theoretical Model," J. Educ. Bus., 2010, doi: 10.1080/08832321003604938.

[12] G. A. Boyne, "Public and private management: What's the difference?," J. Manag. Stud., 2002, doi: 10.1111/1467-6486.00284.

[13] M. J. Polonsky, J. Bailey, H. Baker, C. Basche, C. Jepson, and L. Neath, "Communicating environmental information: Are marketing claims on packaging misleading?," J. Bus. Ethics, 1998, doi: 10.1023/A:1005731914135.

[14] Y. Khodary, "Good governance: A new perspective for institutional reform - A comparative view of water, education and health institutions in Egypt," Int. J. Public Pol., 2016, doi: 10.1504/IJPP.2016.079747.

[15] R. Samin, "Reformasi Birokrasi," jurmal FISIP Umr., 2011. 
[16] S. La Tamba, A. Azis, and K. Bailusy, "Analysis Of Institutional Actors In Rice Policy Implementation In South Sulawesi Province, Indonesia," Adv. Soc. Sci. Res. J., 2015, doi: 10.14738/assrj.212.1659.

[17] J. M. Keung Lo, "Urban Government and Administrative Reform in Post-Mao China: Issues, Trends and Future Directions," Int. J. Public Sect. Manag., 1993, doi: $10.1108 / 09513559310046810$.

[18] M. S. Haque, "New directions in bureaucratic change in Southeast Asia: Selected experiences," J. Polit. Mil. Sociol., 1998.

[19] B. Bozeman, R. B. Ripley, and G. A. Franklin, "Bureaucracy and Policy Implementation," J. Policy Anal. Manag., 1983, doi: 10.2307/3323327.

[20] D. M. Ali, M. I. Islamy, B. Supriyono, and M. R. K. Muluk, "Bringing Local Wisdom-Based Local Government into Practice : A Quadrant Strategy Analysis," Public Policy Adm. Res. IISTE, 2013.

[21] J. D. Rivera, "Representative Bureaucracy, Street-Level Bureaucrats, and Bureaucratic Discretion in Federal Disaster Assistance," J. Public Manag. Soc. Policy, 2016.

[22] L. F. Carter, S. Krislov, and D. H. Rosenbloom, "Representative Bureaucracy and the American Political System,” Am. Polit. Sci. Rev., 1982, doi: 10.2307/1963752.

[23] The World Bank Group, "Beyond Connections: Energy Access Redefined," World Bank, 2015.

[24] European Union, "Directive 2001/20/EC of the European Parliament and of the Council," Approx. laws, Regul. Adm. provisions Memb. States Relat. to Implement. good Clin. Pract. Conduct Clin. trials Med. Prod. Hum. use, 2001.

[25] A. Dwiyanto, "MEMBANGUN SISTEM PELAYANAN PUBLIK YANG MEMIHAK PADA RAKYAT," Populasi, 2016, doi: 10.22146/jp.11830.

[26] P. Kovač, N. Tomaževič, A. Leben, and A. Aristovnik, "Reforming public administration in Slovenia: Between theory and practice of good governance and good administration," Int. J. Public Pol., 2016, doi: 10.1504/IJPP.2016.079732.

[27] Republik Indonesia, "Rencana Pembangunan Jangka Menengah Nasional 2015-2019," Rencana Pembang. Jangka Menengah Nas. 2015-2019, 2015, doi: 10.1017/CBO9781107415324.004.

[28] M. Miles and A. Huberman, "Miles and Huberman Chapter 2," in Qualitative Data Analysis, 1994.

[29] Sugiyono, Metode Penelitian Kuantitatif, Kualitatif dan R\&D. Bandung: Alfabeta, 2014.

[30] S. Morrow, "Management of change," Int. J. E-Learning Corp. Gov. Heal. High. Educ., 2015.

[31] J. H. Pieterse, M. C. J. Caniëls, and T. Homan, "Professional discourses and resistance to change," J. Organ. Chang. Manag., 2012, doi: 10.1108/09534811211280573. 